University of Michigan Law School

University of Michigan Law School Scholarship Repository

Book Chapters

Faculty Scholarship

2020

\title{
The Law and Policy of Child Maltreatment
}

Frank Vandervort

University of Michigan Law School, vort@umich.edu

Available at: https://repository.law.umich.edu/book_chapters/166

Follow this and additional works at: https://repository.law.umich.edu/book_chapters

Part of the Constitutional Law Commons, Criminal Law Commons, Juvenile Law Commons, and the Legislation Commons

\section{Publication Information \& Recommended Citation}

Vandervort, Frank E. "The Law and Policy of Child Maltreatment." In Handbook of Interpersonal Violence and Abuse Across the Lifespan, edited by Robert Geffner, Jacquelyn W. White, L. Kevin Hamberger, Alan Rosenbaum, Viola Vaughan-Eden, and Victor I. Vieth, 1-22. 1st ed. New York: Springer International Publishing, 2020.

This Book Chapter is brought to you for free and open access by the Faculty Scholarship at University of Michigan Law School Scholarship Repository. It has been accepted for inclusion in Book Chapters by an authorized administrator of University of Michigan Law School Scholarship Repository. For more information, please contact mlaw.repository@umich.edu. 


\title{
The Law and Policy of Child Maltreatment
}

\author{
Frank E. Vandervort
}

\section{Contents}

Introduction $\ldots \ldots \ldots \ldots \ldots \ldots \ldots \ldots \ldots \ldots \ldots \ldots \ldots \ldots \ldots \ldots \ldots \ldots \ldots \ldots \ldots \ldots \ldots \ldots \ldots \ldots \ldots, 2$

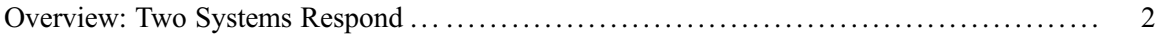

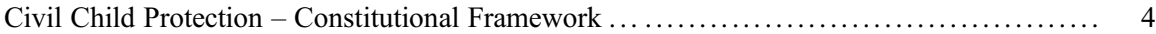

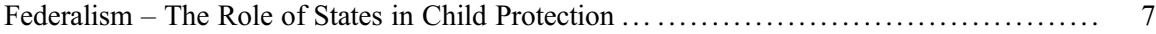

The Role of Federal Statutes ................................................ 8

Child Abuse Prevention and Treatment Act .................................. 9

Adoption Assistance and Child Welfare Act ..................................... 9

Multiethnic Placement Act and the Interethnic Placement Provisions ................. 11

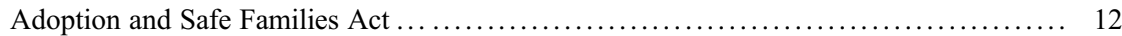

Family First Prevention Services Act ...................................... 13

Criminal Law's Response to Child Maltreatment ................................. 14

Criminal Prosecution of Child Maltreatment - Constitutional Framework $\ldots \ldots \ldots \ldots \ldots \ldots \ldots \ldots \ldots$

Prosecutorial Discretion .............................................. 15

Constitutional Protections for Defendants .................................. 16

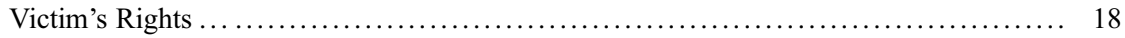

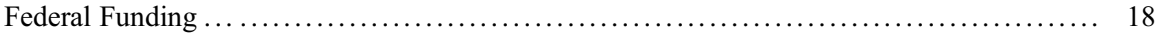

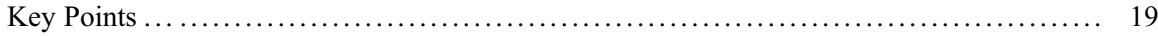

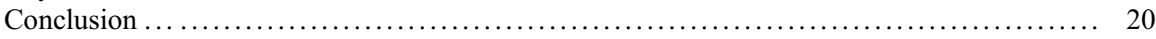

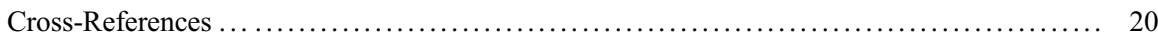

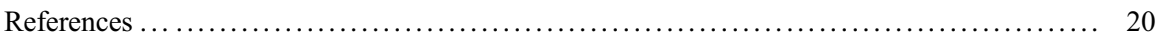

\section{Abstract}

Each year in the United States some four million children are reported to child protective services and hundreds of thousands of children are confirmed victims of maltreatment. This chapter provides a brief overview of the civil and criminal

This chapter was initially published with an incorrect copyright holder name. It has been corrected to (C) Springer Nature Switzerland AG.

F. E. Vandervort $(\bowtie)$

University of Michigan, Ann Arbor, MI, USA

e-mail: vort@umich.edu 
law's response to child abuse and neglect. It summarizes the major federal statutes that provide funding to the states to support both civil and criminal law responses to maltreatment. It discusses the division of responsible for responding to child maltreatment between the federal and state governments (federalism). It also provides a summary of the constitutional framework for handling both civil and criminal child maltreatment cases.

\section{Keywords}

Abuse $\cdot$ Neglect $\cdot$ Maltreatment $\cdot$ Child maltreatment $\cdot$ Law $\cdot$ Child protection $\cdot$ Criminal law $\cdot$ Civil law $\cdot$ Federalism $\cdot$ Constitutional rights

\section{Introduction}

Each year in the United States, state child protection agencies receive approximately 4.0 million reports of suspected abuse or neglect. In Fiscal Year 2017, 3.5 million children were the subject of formal child abuse and neglect investigations or alternative responses to such investigations; after investigation, 674,000 children were deemed victims of abuse or neglect and some 1720 children died from child maltreatment (Administration on Children and Families 2019). These official numbers are widely believed to represent an undercount of the true numbers of children who are maltreated (Myers 2006).

Broadly speaking, the law takes two approaches to responding to child abuse or neglect. One is civil, which focuses primarily on cases involving abuse or neglect at the hands of the child's parent, guardian, or legal custodian. (Child maltreatment may also be litigated in child custody proceedings or in personal injury actions; space limitations preclude discussion of these in this chapter.) The other approach is criminal, which may involve the child's parent or another person responsible for harming the child.

\section{Overview: Two Systems Respond}

The civil law provides a means of investigating alleged child maltreatment within the child's immediate family. In this context, "the child's health and safety shall be the paramount consideration" of the child protection system (42 U.S.C $§ 671(\mathrm{a})(15)(\mathrm{A})$ ). In the first instance, even when a child has experienced maltreatment, these efforts typically focus on preserving and strengthening the child's family. Some argue that the efforts to preserve families in which children have been maltreated are excessive, placing children at unnecessary risk of further harm (Bartholet 1999; Gelles 1996). When children are not safe in their home, the law provides that state juvenile and family courts may remove children from parental custody and place them with a relative or in foster care. Civil child protective proceedings are intended to protect children from harm rather than to punish the parent (e.g., In re M.M. 2015). In People 
v. Moreno (2001), the Illinois Court of Appeals, in holding that the determination of a child protective proceeding could not preclude a subsequent criminal prosecution for the same underlying conduct, noted that "The differences of purpose and goal in civil and criminal proceedings are "very real" (p. 253). Similarly, the Vermont Supreme Court has noted, "a criminal case seeks to identify any misconduct on the part of the defendant" while a civil child protection case "seeks to identify how to best protect the child, regardless of whether or not the child's parent has engaged in misconduct" (State v. Nutbrown-Covey 2017, p. 371). Punishment is reserved exclusively for criminal proceedings.

While cases involving very serious forms of maltreatment may result in proceedings to immediately terminate a parent's rights, in most cases, even after a finding that a parent has maltreated, failed to provide for, or failed to protect a child, the state must make "reasonable efforts" to maintain the child in the parental home before the child may be removed. Similarly, after removal "reasonable efforts" are typically required to address the problems that necessitated the removal and in order to reunify the child with his or her caregivers before any alternative permanent arrange for the child's care in the form of adoption or permanent legal guardianship may be pursued (Bartholet 1999).

In order to protect and provide care for children while their parents or caregivers are working on a program of rehabilitation, each state operates, at substantial expense, a program of substituted care. On September 30, 2017, there were nearly 443,000 children in the foster care system in the United States. During Fiscal year 2017, some 690,500 children spent some time in care. In the midst of the current opioid epidemic, the number of children needing foster care placement has increased in each of the five previous years for which numbers are available (Administration on Children and Families 2019).

In addition to protecting children from harm and remediating the dysfunctions within the family that caused the harm, the civil law provides an administrative scheme that seeks to protect children from further harm by the identified perpetrator of the maltreatment. To this end, each state maintains a registry of individuals found to be responsible for maltreating a child. These registries are available to a limited universe of persons - social service agencies, law enforcement, and employers conducting background checks of individuals involved in certain professions (e.g., day care providers or teachers).

The criminal law provides a second legal mechanism to respond to child abuse and neglect. Unlike civil proceedings, criminal actions seek to identify a specific perpetrator of child maltreatment and to impose punishments for crimes including child neglect, physical and sexual abuse, or sexual exploitation (e.g., producing or distributing child pornography or trafficking children). These crimes may be either misdemeanors or felonies. Also unlike child protective proceedings, criminal proceedings may focus on members of the child's immediate family, members of the extended family (e.g., grandparents, cousins), other members of the child's social circle such as teachers, coaches or clergymen, or complete strangers.

Child maltreatment may violate laws exclusively enacted to protect children from abuse or neglect or may violate general laws such as statutes prohibiting assaultive 
behavior or homicide offenses. In some circumstances, criminal proceedings may, in addition to punishments, impose administrative burdens aimed at monitoring the offender, sometimes for life. Sex offender registration is an example of this type of regime (e.g., Smith v. Doe 2003).

This chapter will provide a summary of the primary ways that the civil and criminal law respond to child abuse and neglect. The reader is cautioned that because the vast majority of specific law relating to child maltreatment is enacted by the individual states, there may be substantial variation in the law and how it is applied to particular cases. The chapter turns next to a discussion of the civil law's response to child maltreatment, and it begins with a discussion of the constitutional authority and limitations governing public efforts to protect children.

\section{Civil Child Protection - Constitutional Framework}

The Constitution of the United States is the supreme law of the land. Neither it nor the Bill of Rights contain to words "child," "parent" or "family." For nearly a century, though, the Supreme Court of the United States has made clear that the Constitution protects the parent-child relationship. In doing so, the Court has struck a balance between the interests of parents in guiding their children's upbringing, the rights of children in deriving the benefit of parenting choices and freedom from parental maltreatment, and the parens patriae interests of the state as the ultimate guardian of the child to regulate or prohibit harmful parenting practices. Within this framework, every state has enacted statutes aimed at responding to incidences of child maltreatment at the hands of a parent.

The seminal case establishing the rights of parents to raise their children free of undue governmental interference is Meyer v. Nebraska (1923). During World War I, Nebraska enacted a law prohibiting the teaching of any modern language other than English (ancient languages - Latin and Greek - were excepted from the law) or the teaching of any subject in a modern foreign language to children who had not yet passed the eighth grade. Robert Meyer, a parochial school teacher, was criminally charged under the statute for teaching 10-year-old children in his classroom to read in German. After his conviction, he appealed, arguing that the law violated his right to liberty as provided for in the Fourteenth Amendment to the Constitution. The Court ruled in Meyer's favor and overturned his conviction. The Court held that in addition to one's physical liberty, the Amendment protected "the right of the individual ... to engage in any of the common occupations of life." This includes the right "to marry, establish a home and bring up children, to worship God according to the dictates of his own conscience, and generally to enjoy those privileges long recognized at common law as essential to the orderly pursuit of happiness by free men" (Meyer v. Nebraska, p. 399). Thus, the court recognized that "it is the natural duty of the parents to give his children education suitable to their station in life" (Meyer v. Nebraska 1923, p. 400). Since parents had this "natural duty," the Court reasoned, they had the right under the Fourteenth Amendment to engage Mr. Meyer to educate their children in order to discharge their duty to their 
children. While the State may "go very far ... in order to improve the quality of its citizens," the Court reasoned further, "the individual has certain fundamental rights which must be respected" (Meyer 1923, p. 401).

Because Meyer involved the criminal prosecution of a teacher, it did not precisely implicate a parents' rights to guide their child's upbringing. Two years after Meyer was decided, in Pierce v. Society of the Sisters of the Holy Names of Jesus and Mary (1925), the Court confronted a similar dispute that squarely addressed the rights of parents to make parenting decisions for their children. Oregon law compelled every child between the ages of 8 and 16 to attend a public school. The Society of Sisters, which ran a catholic school, a military academy and a group of parents challenged the law as violating the parents' liberty interest in directing the educational upbringing of their children. The Supreme Court ruled in favor of the parents, holding the statute unconstitutional. In doing so, the Court noted that, "The child is not a mere creature of the state; those who nurture him and direct his destiny have the right, coupled with the high duty, to recognize and prepare him for additional obligations" (Pierce v. Society of Sisters, p. 535).

Together Meyer and Pierce established the principle that parents have a fundamental right to guide their children's upbringing. At the same time, the Court intimated that the state retained considerable power to regulate education and, more broadly, was not without power to regulate a number of childrearing practices. Prince v. Massachusetts (1944) addressed the limitations on parental decisionmaking authority regarding a child. That case involved the application of the state's law regulating child labor. A statute prohibited children of certain ages from engaging in certain activities. Sarah Prince permitted her two children and another child whom she served as legal guardian to sell religious pamphlets on the streets of for $\$ .05$, which resulted in her being criminally charged with violating the state's child labor laws.

The case raised two issues before the Supreme Court. First, it addressed the right of a parent to direct her child's religious development. The second issue was the right of the child to participate in his or her family's religious practices. In Prince, the Court articulated the two parties' competing interests in child rearing - the interest of parents to raise their children without governmental interference and the right of State authorities to protect a child's welfare. "It is cardinal with us that the custody, care, and nurture of the child reside first with the parents." The Court went on to make clear, however, that "the family is not beyond regulation in the public interest" (p. 167). Indeed, "neither the rights of religion nor the rights of parenthood are beyond limitation. Acting to guard the general interest in youth's well-being, the state ... may restrict the parent's control" (p. 166) in numerous ways, including through compulsory education laws and laws prohibiting child labor. The Court was clear that "the state has a wide range of power for limiting parental freedom and authority in things affecting child welfare" (Prince v. Massachusetts 1944, p. 167). Years later, in a case that adjudicated the rights of Amish parents to discontinue their children's formal education after age 13 in the face of a state statute that required that children remain in school until they were 16, the Court summarized the relationship of parent and state. American history and culture, the Court said, "reflect a strong 
tradition of parental concern for the nurture and upbringing of their children." It continued, "This primary role of the parents in the upbringing of their children is now established beyond debate." The Court, however, made clear that "the power of the parent ... may be subject to limitation under Prince if it appears that parental decisions will jeopardize the health or safety of the child, or have a potential for significant social burdens" (Wisconsin v. Yoder 1972, pp. 233-234). Thus, either harm to the child and the burdening of the public may legitimately trigger state intervention into family life. Child maltreatment implicates both of these legitimate governmental concerns.

The rights of child in this tripartite analysis are somewhat less well-defined. Generally in the child protection context, children's rights correspond to their parents' rights. In Duchesne v. Sugarman (1977), the Court described the relationship this way: The "right to the preservation of family integrity encompasses the reciprocal rights of both parent and children. It is the interest of the parent in the companionship, care, custody and management of his or her children ... and of the children in not being dislocated from the 'emotional attachments that derive from the intimacy of daily association,' with the parent" (p. 825).

The state's interest in a child's welfare is at its zenith in the child protection context, where the state possesses an "urgent interest in the welfare of the child" (Lassiter v. Department of Social Services 1981, p. 27). Because of the importance of the state's interest, Courts have made clear there is no constitutional right to remain together as a family (e.g., Anh v. Levi 1978). Thus, a juvenile or family court may order a child removed from his or her parent's custody in order to protect the child from maltreatment. The Supreme Court has suggested, without yet squarely holding, that the reciprocity of the parent-child relationship precludes state authorities from assuming at the adjudication phase of a child protection case that the parent and the child are adversaries. Only after the state has demonstrated parental unfitness (i.e., that the parent is in some way abusive or neglectful) may governmental authorities assume that the interests of the parent and the child diverge (Santosky v. Kramer 1982).

In the course of adjudicating the rights of parents and children in the child protection context, the law requires fundamentally fair procedures. This includes written notice of the allegations against the parent, the opportunity to be heard, and the right to have a neutral decision-maker (judge or jury) determine the facts of the case. There is no absolute constitutional right for a parent to be provided a lawyer at public expense if the parent cannot afford to hire legal counsel (Lassiter v. Department of Social Services 1981), though most states, either as a matter of state constitutional law or by statute, provide a lawyer at public expense for indigent parents. When the State seeks to terminate a parent's parental rights, it must prove by clear and convincing evidence that there is a legally justifiable reason to do so (Santosky v. Kramer 1982). If a parent whose rights have been terminated by a trial court wishes to appeal, the Due Process and Equal Protection Clauses of the Fourteenth Amendment guarantee the right to have a transcript of the trial court proceedings provided to the parent at public expense (M.L.B. v. S.L.J. 1996). 


\section{Federalism - The Role of States in Child Protection}

Beyond the basic procedural framework of liberty, due process, and equal protection required by the Constitution, "The whole subject of domestic relations of husband and wife, parent and child, belongs to the laws of the States, and not to the laws of the United States" (In re Burrus 1890). Thus, federal courts lack subject matter jurisdiction (i.e., the authority) to consider collateral attacks on a state court's decision to terminate a parent's parental rights and the federal right of habeas corpus is not available in this context (Lehman v. Lycoming County Children's Services Agency 1982). The rationale for this division of authority between the federal government and the individual states - i.e., federalism - is that "a healthy balance of power between the States and the Federal Government will reduce the risk of tyranny and abuse from either front" (Gregory v. Ashcroft 1991, p. 458).

Federalism, then, reserves the substantive law of child protection to each individual state as part of each state's general family law. Each state may define for itself what constitutes a "child," what constitutes "child abuse," what constitutes "child neglect," and the procedures by which child protection cases will be proceed through the state court system (e.g., In the Interest of L.J.B. 2018; New Jersey Division of Child Protection and Permanency v. Y.N. 2014). To illustrate, in In the Interests of L. $J . B$ (2018), the Pennsylvania Supreme Court held that a mother's use of illicit drugs during her pregnancy could not form the basis for the juvenile court to assume authority over a newborn baby. Under Pennsylvania law, the parties agreed that a fetus was not a "child" within the meaning of the child protection law. Because the fetus was not a "child" the mother could not properly be found to be a perpetrator of child abuse. Similarly, the New Jersey Supreme Court held that where a woman who was addicted to heroin became pregnant and, upon learning she was pregnant, entered a methadone treatment program then gave birth to a baby who experienced withdrawal because of the methadone dependence, the juvenile court could not take jurisdiction of the baby immediately upon birth. In the Court's view, the mother's use of methadone under a doctor's care and as part of legitimate treatment program alone did not constitution neglect within the meaning of the state's law. The court held, however, that if there were other neglectful acts by the mother (e.g., ongoing illicit drug use, inability to provide for the baby), that could be considered neglect ( $\mathrm{New}$ Jersey Division of Child Protection and Permanency v. Y.N. 2014). By comparison, a number of state appellate courts have ruled that substance abuse during pregnancy itself is sufficient to courts child protective authority immediately upon the child's birth (e.g., In re Baby X 1980; In re Troy D. 1989). In the seminal case in this line, the appellate court noted that, "a child has a right to begin life with sound mind and body” (In re Baby X 1980, p. 115).

There is one exception to the general rule that child protection is left to the individual states. That exception is embodied in the Indian Child Welfare Act (1978) (ICWA), which was enacted in 1978. The Constitution of the United States provides that relations with Indian Tribes are to be governed by the federal government through the so-called Indian Commerce Clause rather than by the individual states (Const. U.S., Art. 1, Sec. 8, Cl. 3). The ICWA came about as a result of a long history 
of efforts to assimilate Indian children into the dominant white culture through abusive child welfare practices, which resulted in as many as one-third of all Indian children being removed from their parents' custody for placement in foster or adoptive homes. Those substitute care providers were predominantly white. Additionally, Indian children historically and culturally were raised as part of a tribe or band in which a more communal childrearing ethic was operative. The same practices that led to the excessive removal of children from their parents disregarded the role of the tribe in the child's life. The ICWA addressed these concerns by mandating that when state child protection authorities seek to remove an "Indian child" from his or her home. By its terms, the statute applied only to an "Indian child," which it defines as an unmarried person under 18 who is a member of a tribe or is eligible for membership in a tribe and is the biological child of a member of a tribe (25 U.S.C. $\S 1903(4)$ ). Because of this definition, the ICWA may not apply to all children who identify as Native American and may apply to one member of a sibling group and not another. Each tribe defines for itself its membership. When handling a case involving an "Indian child," state courts must comply with a series of procedural requirements that are specifically intended to make removal of the child from parental custody more difficult. In part because the statute makes removal more difficult, it has been controversial since its enactment. Among the ICWA's procedural requirements are higher standards of evidence for initial removal and termination of parental rights, a requirement that "active efforts" be made first to prevent the child's removal from the parent's custody then to try to address the problems that made removal necessary and reunify the child with the parent. The law also requires expert testimony by at least one individual knowledge in tribal child rearing practice (Fletcher et al. 2009).

\section{The Role of Federal Statutes}

Because state law governs the substance of parent-child relations except in the context of Indian children, the primary way in which the federal government influences the handling of child protection cases is through its power to expend money. The Constitution's spending clause permits the federal government to spend money to support state policies it wishes to see implemented, and to withhold money when a state's policies do not comply with federal priorities or prerogatives. Basically, through funding statutes, the federal government establishes a source of financial support that the individual states and Indian tribes can access contingent on their implementation of the various requirements of the relevant federal statute. Unless otherwise explicitly provided for in these funding statutes, the Supreme Court has held, such laws do not create an individual right that is enforceable by particular persons. Thus, for example, in Suter v. Artist M. (1992), the Court held that an individual could not bring suit under the federal civil rights law alleging a violation of the "reasonable efforts" requirement contained in Title IV-E, which funded foster care services. This principle has been codified in some portions of the law, for example, Title IV-B of the Social Security Act, which funds some child 
welfare services, explicitly states that it does not "entitle any individual or family to assistance under any State program funded under this part" (42 U.S.C.§ 601(b)). By contrast, the Multiethnic Placement Act as amended by the Interethnic Placement Provisions explicitly grants the right to sue to any person who is aggrieved as a result of its violation (42 U.S.C. 674(d)(3)).

What follows is a brief summary of the major federal legislation addressing child maltreatment and foster care.

\section{Child Abuse Prevention and Treatment Act}

Before the mid-1970s, the federal government played little role in child protection (Myers 2006). With the enactment of the Child Abuse Prevention and Treatment Act in 1974 (CAPTA), Congress began to provide funding to the individual states in an effort to prevent child maltreatment and to support states' efforts to protect children from parental abuse and neglect. A state's access to those funds is contingent on the state complying with the statute's various, specific requirements. These include such things as a program of mandated reporting of suspected child abuse or neglect, immunity for those mandated reporters, a requirement that children's protective services (CPS) agencies investigate cases of human trafficking involving children and that cases of children born after being prenatally exposed to alcohol or illicit drugs be reported to CPS. CAPTA has been renewed and amended numerous times since it was initially enacted. With each renewal, the list of specific requirements with which states must comply grows more detailed (Children Bureau 2019).

In addition to funding state programs aimed at preventing and responding to child maltreatment, CAPTA established a program to conduct research as to the causes and consequences of child abuse and neglect. This program, in part, seeks to identify best practices and then to promote their adoption in communities across the country.

\section{Adoption Assistance and Child Welfare Act}

Also in the mid-1970s, Congress took up issues related to the foster care system. In 1959, Mass and Engler published a major study that found that children who entered the foster care system very often stayed for years (Maas and Engler 1959). Far too often, there was no plan nor any effort either to return these children to their biological family or to sever permanently parental rights making them available for adoption into a new family. Children moved frequently, from one family to another or into institutional settings. Large numbers of children left foster care through aging out. These elements of "foster care drift" and "limbo" persisted into the 1970s (Fanshel and Shinn 1978). Two cases decided by the US Supreme Court in that era illustrate these problems. First, in Smith v. Organization of Foster Families for Equality \& Reform (1977) a group of foster parents sued New York City's (NYC) child welfare agency seeking court orders that the agency's procedures for removing children from their homes violated their right to due process of law. The Court ruled 
against the foster parents. In doing so, it noted that a foster child in NYC spent an average of 4 years in the system, and that some of the children at issue in the case had been with their foster families for 10 years. The second case, Santosky v. Kramer (1982), also from New York, involved three children. The first entered foster care in November 1973, the other two in September 1974. In September of 1976, the agency sought to terminate the parents' rights to the children. The trial court denied this request and continued the children in temporary foster care. Two years later, in October 1978, the agency again petitioned to terminate parental rights, which the trial court granted. The parents appealed, and the Supreme Court decided the case in 1982 , reversing the state courts' decision to terminate the parents' rights and sent the case back to the state trial court for further proceedings.

Congress's response to foster care "drift" and "limbo" was to pass the Adoption Assistance and Child Welfare Act of 1980 (AACWA). Broadly speaking, the AACWA had three goals. First, it sought to reduce the number of children entering the foster care system by mandating, as a contingency to taking federal money, that states make "reasonable efforts" to reduce the placement of children into out-ofhome care. Next, the statute sought to ensure that foster care was temporary and to shorten the time children spend in foster care. It accomplished this by mandating "reasonable efforts" be made to return children to their families. It also mandated that a permanency planning hearing (PPH) 18 months after the child entered foster care. The PPH's purpose was to force a decision to return the child to his or her biological parents or to move to terminate parental rights so that the child could be adopted. Finally, to move children out of the foster care system, the law established a program of adoption assistance that provides financial support in the form of cash stipends and Medicaid support for adoptive families while requiring that states again undertake "reasonable efforts" to finalize an adoption plan for the child.

To carry out the mandates of the AACWA, Congress created two new titles within the Social Security Act (the Act). Title IV-B of the Act (42 U.S.C. § 621, et sec.) funds family preservation services for families involved with CPS. Its goals are:

1. Protecting and promoting the welfare of all children

2. Preventing the neglect, abuse, or exploitation of children

3. Supporting at-risk families through services which allow children, where appropriate, to remain safely with their families or return to their families in a timely manner

4. Promoting the safety, permanence, and well-being of children in foster care and adoptive families

5. Providing training, professional development and support to ensure a well-qualified child welfare workforce

The AACWA also added Title IV-E to the Act, which established a stream of funding to support foster care for children in need of those services, family reunification services while children were in foster care and the adoption assistance program. 


\section{Multiethnic Placement Act and the Interethnic Placement Provisions}

Historically, children of color were denied access to many child welfare services (Vandervort 2016). More recently, there has been concern about the overrepresentation of children of color in the child protection system (e.g., McRoy 2005). Related to this issue has been a long and sometimes contentious debate about cross-racial adoption (Kennedy 2003; Bartholet 1999). Children of color, particularly African American children, have represented a group of special concern in relation to foster care. These children tend to spend more time in foster care and spend more time awaiting adoptive families (Myers 2006). This was, in part, due to race matching policies, which required efforts to match children in need of foster care or adoption with families of the same race. Foster care services are often provided through private, sectarian foster care agencies. For example, for many years children entering New York City's (NYC) foster care system were provided homes through religiously affiliated foster care organizations that matched their family's religion. Jewish children, for example, were placed through Jewish foster care programs while children from Catholic families through Catholic agencies. Black children tended to be Protestant and were placed through Protestant agencies, which lacked sufficient resources to meet the demand. The American Civil Liberties Union's Children's Rights Project brought suit on behalf of black Protestant children against NYC seeking to end the practice of religious matching in placement. The parties reached a settlement that required children to be placed on a first come, first served basis, which the Federal District Court approved. The sectarian agencies appealed to the Federal Circuit Court of Appeals for the Second Circuit, which upheld the agreement against religion-based First Amendment claims (Wilder v. Bernstein 1988).

To address the problem of delay in foster care and adoptive placement to accommodate race-matching practices, Congress, in 1994, passed and the President signed into law the Multiethnic Placement Act (MEPA). It amended Title IV-E with the intent of eliminating the "routine" consideration of race, color, or national origin in foster care and adoptive placement (Mutiethnic Placement Act (MEPA) 1994). The prohibition on "routine" race matching, however, proved easy to circumvent. So, 2 years later, Congress passed the Interethnic Adoption Provisions, which barred outright the consideration of race, color, or national origin in making placement decisions except in very narrow, case specific, circumstances.

MEPA-IEP took several other steps to eliminate race-matching practices. First, it imposed significant financial penalties on states for its violation. Next, it required that states put in place policies to recruit foster and adoptive homes that would meet the needs of children entering the system, which responded to the historical denial of persons of color from fostering and adopting, either by explicit prohibition or by the implementation of race-neutral policies that disproportionately impacted applicants of color. The statute, as noted earlier, explicitly granted any person, adult or child, aggrieved by its violation an individual right to sue (Vandervort 2016). 


\section{Adoption and Safe Families Act}

Shortly after the enactment of the AACWA, the United States began to experience an epidemic of crack cocaine use, which had many of the characteristics of the opioid epidemic in full swing at this time of this writing. That earlier epidemic hit the child protection system hard and frustrated the intent of the AACWA to reduce the numbers of children entering the foster care system and to shorten children's time in care. Despite the ravages of crack cocaine, child protection agencies overemphasized family preservation to the detriment of children (Gelles 1996; Bartholet 1999). A series of high-profile cases in which children were murdered or maimed by parents after repeated instances in which violent families were preserved or children reunified with parents who had presumably been successfully rehabilitated were featured in the nation's mass media (e.g., Terry 1996; Hentoff 1988). For example, the beating death of Eli Creekmore, a 3-year-old from Washington State (Hentoff 1988), which was the subject of numerous local and national stories in the print media as well as a documentary on Public Broadcasting, and David Edwards, the child at the center of Richard J. Gelles's 1996 The Book of David (Gelles 1996). Joshua DeShaney was another such child whose case made its way to the Supreme Court. CPS workers were aware that Joshua's father was physically abusing him. Despite that knowledge, they took no action to remove him from his home and made no meaningful efforts to protect him while he remained in his father's custody. After the father beat Joshua causing serious brain injuries that left him in a coma and permanently brain damaged, Joshua's mother sued CPS on behalf of her son, claiming that CPS's inaction violated Joshua's civil rights. The Supreme Court ultimately dismissed the suit, ruling that the child had no right to protection from the state's child protection apparatus (DeShaney v. Winnebago County Department of Social Services 1989).

By 1997, Congress grew concerned that its intention in requiring "reasonable efforts" to preserve and to reunify families had been misconstrued by federal bureaucrats and state child protection agencies. To clarify its intent, Congress passed the Adoption and Safe Families Act (1997) (ASFA), which amended Titles IV-B and IV-E. While it retained the "reasonable efforts" requirement and provided more funding for family preservation programming, the amendments made clear that the child's safety was to be the paramount consideration of child welfare agencies. For the first time it defined a narrow group of egregious cases of maltreatment in which state child welfare agencies would be required to immediately seek termination of parental rights. That is, a group of cases where any efforts to preserve or reunify the child with the parent would be considered per se unreasonable.

Next, ASFA permitted states to define additional "aggravated circumstances" cases in which the state could elect to forgo family preservation or reunification efforts and move immediately to terminate parental rights. In response, California, for example, enacted a statute that defines 17 specific circumstances when reunification services are unnecessary. These range from cases of severe physical abuse to situations in which the parents participate in chronic substance abuse (California Welfare \& Institutions Code $\S 361.5(b)$ ). 
ASFA also gave state agency personnel the authority to override the "reasonable efforts" requirements in any case in which seeking to reunify a child with a parent is not reasonable. In response, some states enacted statutes to do so. For example, Illinois enacted a statute that permits the state's child protection agency to seek immediate termination of parental rights "in those extreme cases in which the parent's incapacity to care for the child, combined with an extremely poor prognosis for treatment or rehabilitation, justifies expedited termination of parental rights" (705 Ill. Comp. Stat. Ann $\S 405 / 1-2(1)(c))$. In addition, the amendments permitted a state trial court to make any decision in an individual case that would meet the needs of the child without threatening federal funding (42 U.S.C. $§ 678$ ).

In addition to these major revisions, ASFA included numerous additional and procedural requirements to redouble the child protection system's efforts to move children more quickly through the foster care system, to make it truly temporary (Vandervort 2016). Many of ASFA's goals were undermined by the very agency, the Children's Bureau, charged with their implementation. Almost from the moment of its enactment, federal bureaucrats sought to render ASFA ineffective in order to maintain the focus on family preservation and reunification. Two years after its enactment, Harvard Law School Professor Elizabeth Bartholet wrote regarding ASFA, "The child welfare establishment is hard at work today pushing for the development of new programs and the expansion of old ones that are consistent with the family preservation tradition" (Bartholet 1999, p. 28). Despite ASFA's clear mandate that child safety was to guide child protection work, two decades after its enactment, the child's parents were still considered by CPS agencies and caseworkers as the primary focus of child protection services (Dwyer 2016; Gelles 2016).

After ASFA's enactment, a new child welfare program, called differential response (DR) or alternative response (AR), was widely adopted despite a lack of any real empirical support for its effectiveness (Hughes et al. 2013; Gelles 2016). This program is another in a long line of programs that seek to preserve families at the risk of serious harm to children. DR/AR forgoes an investigation relying instead on an allegedly more compassionate "family engagement" approach in an effort to address problems of child maltreatment. The program's goal is to divert "a large percentage of the cases that traditionally are under child protective services jurisdiction to a new voluntary ... track" (Gelles 2016, p. 752).

\section{Family First Prevention Services Act}

The Family First Prevention Services Act (FFPSA) was signed into law in February 2018. At this writing, the statute is in the process of implementation, with most of its various provisions due to be in effect in late 2019 and 2020. As the name of the statute suggests, this statute is a reversion back to the aggressive family preservation program in the 1980s and 1990s. Although DR/AR programs have been heavily criticized as lacking a solid empirical base (Bartholet 2015; Hughes et al. 2013), the FFPSA seems to adopt them as a primary means of doing the business of child 
protection (Administration for Children and Families 2018). In doing so, the new focus seems to suggest that the problem of child protection is placement in foster care rather than the harms that result from parental abuse and neglect, and to see poverty rather than adult dysfunction as the primary cause of child maltreatment. While poverty contributes to child maltreatment, the vast majority impoverished parents do not maltreat their children and never come into contact with CPS. Focusing on poverty also begs the question of what drives the poverty these families experience. The highly dysfunctional parents entangled in the child protection system are very often poor because they abuse drugs, suffer from mental health problems that they cannot or will not address, live in violent relationships, and so on. Most parents involved with the child protection system suffer from several of these dysfunctions at one time, and this comorbidity drives them ever deeper into the child protection system and make providing rehabilitative treatment more difficult. These parents are not in the system because they are poor. They are poor because they have a multiplicity of functional problems that impair their capacity to safely parent their children (Gelles 2016).

The FFPSA requires that therapeutic services provided to children must be trauma-informed and evidence-based. The statute provides three levels of evidence-based services - promising, supported, or well-supported. The Children's Bureau will establish a vetting procedure to ensure that services are evidencebased 42 U.S.C. $\S 671(\mathrm{e}))$.

Time will tell how the FFPSA will be implemented and what impact it will have. The initial policy guidance from the Children's Bureau is not encouraging and, given our previous experience with aggressive family preservation services, suggests that children will be placed at increasing risk of serious harm. When the civil law's child protection system fails to protect children from maltreatment, the criminal law often takes over. That was the case with Joshua DeShaney's father. He was convicted of criminal child abuse and spent 2 years in prison, though his son, who suffered until his death as a result of the abuse he experienced (Stephenson 2015).

\section{Criminal Law's Response to Child Maltreatment}

Whereas the civil law's response to child maltreatment focuses primarily on child abuse or neglect within the family, the criminal law's response is broader. It implicates both those adults who are legally responsible for a child's care (e.g., parents, guardians) and those who are not, including those who may have no acquaintance with the child at all. Unlike the civil context discussed above, criminal proceedings alleging child maltreatment seek to identify a specific perpetrator of the abuse or neglect and to impose punishments commensurate with the harm caused. Criminal charges involving child maltreatment may involve either adults or juveniles. While juvenile proceedings may technically be civil, they require most of the same procedural protections required of adult criminal prosecution (In re Gault 1967). Juveniles charged with more serious offenses may be tried as an adult. For 
example, in one high-profile case, a 12-year-old boy was charged and convicted as an adult with murder in the beating death of a 6-year-old (e.g., State v. Tate 2003).

\section{Criminal Prosecution of Child Maltreatment - Constitutional Framework}

As discussed in the civil context, the Constitution envisions a limited role for the federal government, leaving most of the substantive criminal law to the individual states (Brecht v. Abrahamson 1993). This principle of federalism means that only where the prohibited conduct "substantially affects" interstate commerce may Congress impose criminal sanctions (United States v. Lopez 1995, p. 559). In United States v. Nagarwala (2018), the federal prosecutor charged several medical professionals and four mothers with violating the federal statute prohibiting female genital mutilation (FGM), with conspiracy to violate the FGM statue and with aiding and abetting FGM after the mothers brought their young daughters to doctors to have the procedure performed. The defendants asked the court to dismiss the charges on the grounds that Congress lacked the authority to enact a law prohibiting FGM because it did not substantially affect interstate commerce. The court agreed, found the FGM statute unconstitutional, and dismissed the charges. It is for the states, not the federal government, to regulate this intrastate conduct, the court ruled.

Conversely, when criminal conduct implicates interstate commerce, it is a proper subject for Congress and the federal government to regulate and punish. Thus, for example, a statute making it a federal criminal offense to knowingly possess or distribute child pornography was held to be a proper exercise of Congress's Commerce Clause authority. This is because, although much child pornography is "homegrown," it often "enters the national market surreptitiously" and "Congress, in an attempt to halt interstate trafficking, can prohibit local production that feeds the national market and stimulates demand, as this production substantially affects interstate commerce" (United States v. Holston 2003, pp. 89-90).

\section{Prosecutorial Discretion}

When a law has been properly enacted, the principle of separation of powers between the three branches of government - the legislative, the executive, and the judicial - gives the prosecutor, an executive branch official - broad discretion in determining whether to charge a person with a crime and what charges to bring (e.g., Brodenkircher v. Hayes 1978). Thus, charges for an act of child maltreatment may be brought under statutes enacted specifically to address child abuse or neglect, or they may be brought under more general statutes such as those that punish assaults or homicides. Many states have structured their criminal sexual conduct statutes so that the sexual assault of a child requires the same factual proof as sexual assault of an adult victim, but increase the penalties when the victim is a child. 


\section{Constitutional Protections for Defendants}

The protections contained in the Bill of Rights, applicable to the individual states through the Fourteenth Amendment to the Constitution, as well as the Fourteenth Amendment itself apply to criminal proceedings. When the state seeks to punish an individual citizen for a violation of the criminal law, which may include loss of physical liberty through incarceration, the protections afforded by the constitution are at their strongest. For purposes of this chapter, the discussion will be limited to the First, Fifth, Sixth, and Eight Amendments, which have particular salience in a child abuse or neglect prosecutions. But the reader should be aware that others also apply.

\section{First Amendment}

The First Amendment protects the freedom of speech and the freedom of the press. In Globe Newspaper Company v. Superior Court (1982), the Supreme Court addressed a case from Massachusetts involving a statute that required a trial court to close the courtroom to the public during the trial of certain sex crimes against minors. A defendant was charged with sexually assaulting three minors. As required by the statute, the state trial court ordered the courtroom closed to the press and the public. The Globe Newspapers appealed the order closing the courtroom. The Supreme Court found that the press's access to the courtroom is not an absolute right. Access may be restricted when other competing considerations outweigh the rights of the press and the public. To restrict access, however, 1) the government must articulate a compelling reason for closing the courtroom; and 2) the closing of the courtroom must be narrowly tailored to meet that compelling reason. The Court ruled that neither the government's interest in protecting the child-witnesses from trauma and embarrassment nor its interest in encouraging victims to come forward justified the trial court's action in this case. While the protection of child witnesses is a compelling governmental interest, the law went too far in presuming that every child would be traumatized by testifying in public. Instead, the Court required that a case-by-case determination of harm to the particular child who was to testify and that alternatives to closing the courtroom be considered. As for encouraging victims to come forward, the Court found this rationale dubious.

\section{The Fifth Amendment}

Relevant to this discussion, the Fifth Amendment provides that a person "shall not be compelled in any criminal case to be a witness against himself" (Cons't. U.S., Amend. 5). That is, a person has a right to remain silent when questioned by a police officer or other governmental representative about his or her involvement in a criminal act (e.g., Miranda v. Arizona 1966). The right to remain silent also applies at trial (Griffin v. California 1965). A parent's Fifth Amendment right against selfincrimination is not violated when the court orders the parent to either produce or disclose the whereabouts of a child who has been placed in his or her custody by the court in a child protection proceeding subject to certain monitoring requirements (Baltimore City Department of Social Services v. Bouknight 1990). 


\section{The Sixth Amendment}

Among other things, the Sixth Amendment guarantees that a criminal defendant is entitled to confront the witnesses called by the prosecution. The Supreme Court has decided several cases involving child abuse-related charges with Sixth Amendment implications.

In Crawford v. Washington (2004), the Supreme Court held that a witness's testimonial statements could not be admitted against a criminal defendant without the declarant of those statements being present in court and available for crossexamination by the defendant or his lawyer. Crawford involved a case of domestic violence, which resulted in criminal charges for assault and attempted murder. After the police were called to the scene the victim, the defendant's wife, was interviewed by officers. The officers took her statements in their report. At trial, she did not take the stand because the state's marital privilege law prohibited her from testifying against her husband. At trial, the court allowed the prosecution to admit her statements to the police. After the defendant was convicted, he appealed. The Court ruled that admitting testimonial statements - those made under circumstances that the person making the statement knows or should know that they will be used in court - violated the defendant's confrontation rights and required that the witness appear at trial and submit to cross-examination. For the purposes of this chapter, the general rule that emerged from Crawford is that children must testify when they are the alleged victims of criminal child abuse and they must submit to cross-examination. Once the child testifies his or her out-of-court statements made admissible under the hearsay rules may be admitted for a proper purpose (Vandervort 2013).

In Ohio v. Clark (2015), a 3-year-old boy arrived at his preschool with injuries and bruises to his eye and the side of his head. When the teacher and the principal asked what happened, the child indicated that his mother's paramour had hit him. Prosecutors charged the paramour with child abuse-related offenses. At trial, the prosecution offered the child's hearsay statements to the teacher and principal in lieu of calling the boy as a witness. After he was convicted, the defendant appealed. Applying the rule from Crawford, the Ohio Supreme Court determined that this process violated the defendant's right to confront witnesses against him. The State appealed to the Supreme Court, which revered and reinstated Mr. Clark's conviction. In doing so, it ruled that the child's statements to the school officials were not "testimonial," that is, they were not made for the primary purpose of supporting a criminal prosecution.

In another case, the Supreme Court had to decide whether witness protections for child witnesses (e.g., closed circuit television) utilized in some jurisdictions violate a criminal defendant's confrontation right. In Maryland v. Craig (1990), the trial court made specific findings that the child would be harmed or rendered unable to testify fully by a direct, face-to-face confrontation with the defendant in the course of a child sexual abuse prosecution. The Court held that a defendant's Sixth Amendment right to confront and cross-examine witnesses is not absolute. The state's interest in protecting child witnesses and permitting them to testify fully is an important one. So, the Court held, where the trial court makes findings regarding the specific case 
that testifying in a direct confrontation with the defendant would inflict trauma that is more than de minimus or would render the child-witness unable to testify, the use of child witness protections is justified.

In Pennsylvania v. Ritchie (1987), the Court addressed an issue related to the confrontation right. In that case, the defendant was charged with sexually abusing his daughter. CPS had conducted an investigation. The defendant subpoenaed CPS's records. The agency refused to turn the record over, asserting that it was privileged. Defendant sought a court order for the records, which he claimed he needed to have access to in order to conduct an effective cross-examination of the daughter. The trial court denied him any access to the records. After he was convicted, Ritchie appealed. The state appellate court overturned the conviction ruling that the denial of access to the entire CPS record violated his confrontation right. The state appealed. The US Supreme Court held that Ritchie was not entitled to unrestricted access to the CPS file. Rather, the defendant had a right to have the trial court judge conduct a review of the CPS records and for the judge to determine whether there was any information in the CPS record that might have led to an acquittal. If the CPS record contained such information, it must be turned over to the defendant and he was entitled to a new trial. If the CPS record did not contain such information, Ritchie's conviction was affirmed.

\section{The Eighth Amendment}

The Eight Amendment prohibits the imposition of "cruel and unusual punishment" (Cons't. U.S., Amend. 8). In 2008, the Supreme Court ruled that the Eight Amendment was violated by a Louisiana law that allowed one who rapes a child to be sentenced to death (Kennedy v. Louisiana 2008). The death penalty is available, the Court ruled, only in cases involving homicide.

\section{Victim's Rights}

While neither the Federal Constitution nor the Bill of Rights addresses the rights of crime victims. Both Congress and the states have addressed the rights of crime victims, including victims of child maltreatment offenses. The states have incorporated victim's rights into either their state constitutions or through legislative enactment, or both. Wisconsin enacted the first crime victim's rights statue in 1980. By the 1990s, every state had addressed the rights of crime victims either by amending their state constitution or by enacting legislation (National Institute of Justice 1998).

\section{Federal Funding}

As with civil child protective proceedings, the federalism issues that prohibit the federal government from enacting general criminal laws do not prevent Congress from using its spending power to influence state responses to crime by providing financial incentives to enact laws that Congress supports. For example, the Jacob 
Wetterling Crimes Against Children and Sexually Violent Offender Registration Act (Wetterling Act), which is part of a broader crime control act, the Violent Crime Control and Law Enforcement Act of 1994, provides funding incentives to the states to create sex offender registries for offenders who commit sexually violent offenses or commit various crimes against child-victims.

In part in response to the Wetterling Act, states enacted sex offender registration laws, which have been challenged on a number of grounds. Alaska's registration law, which applied retroactively to previously adjudicated offenders, was challenged as the imposition of a retroactive punishment in violation the Constitution's Ex Post Facto clause in Smith v. Doe (2003). The Supreme Court rejected this challenge. It held that when enacting the registration law, the state legislature's intent was not to punish. Rather, its intent was to establish a civil regime of monitoring sex offenders. Similarly, the Court rejected a challenge to Connecticut's sex offender registration law. That law required information about sex offenders to be available to the public on the Internet, which, it was argued, violated the registrant's right to due process guaranteed by the Fourteenth Amendment (Connecticut Department of Public Safety $v$. Doe 2003). At the time of this writing, the Supreme Court has before it another sex offender registry case, Gundy v. United States (2018), which challenges the federal Sex Offender Registration and Notification Act's delegation of rule-making authority to the Attorney General of the United States. Gundy, who was convicted of failing to register as required by the law when he moved from Pennsylvania to New York, is challenging the rules issued by the Attorney General as a violation of the separation of powers, that is, that the rules make new law rather than merely implement the properly enacted law.

\section{Key Points}

- The law provides two basic responses to child maltreatment, a civil response and a criminal response. The civil response may involve child protection cases typically brought by state child protection authorities, child custody actions initiated by the child's parent, or personal injury actions to seek monetary compensation for injuries to the child. Criminal proceedings seek to identify the perpetrator of child maltreatment and to impose punishment and rehabilitative services on him or her.

- Both civil proceedings and criminal proceedings implicate the constitutional rights of the parties. Civil proceedings implicate the rights of the child, the child's parents, and the state. Criminal proceedings implicate the rights of the defendant and the state. Additionally, criminal proceedings implicate statutory - thought not constitutional - rights of the victim.

- Substantive child maltreatment law is primarily established by the individual states. As a matter of federalism, the constitutionally constructed relationship between state governments and the federal government, individual states determine the substance of the law relating to child maltreatment (e.g., how "child abuse" is defined). 
- The federal government influences state law through a series of funding statutes that provide federal financial support to a state if the state's program and procedures comply with federal law's requirements. Through this funding process, the federal government has come to play a critical role in how individual states handle cases of child maltreatment.

\section{Conclusion}

As this summary demonstrates, most law responding to child maltreatment is state law that operates within a federal framework consisting of constitutional requirements. Congress drives states' child abuse and neglect policies by providing funding to support policy choices Congress wishes to see implemented.

\section{Cross-References}

$\checkmark$ Child Abuse Offenders

$\checkmark$ Child Protective Services, Child Welfare, and Foster Care

Criminal Justice

- Images of Sexually Abused Children/Pornography

Legal Reforms

- Neglect of Children

- Overview of Child Maltreatment

- Physical Abuse

- Physical Neglect

> Policies and Laws: Mandated Reporting

- Sexual Abuse of Children

- System Responses to Child Maltreatment

- System Responses to Child Maltreatment: Justice (Legal/Forensic)

\section{References}

Administration for Children and Families. (2018, November 16). Log no: ACYF-CB-IM-18-05. Retrieved from https://www.acf.hhs.gov/sites/default/files/cb/im1805.pdf

Administration for Children and Families. (2019). Administration on children, youth and families, children's Bureau. The AFCARS report. Retrieved from https://www.acf.hhs.gov/sites/default/ files/cb/afcarsreport25.pdf. Visited 25 Apr 2019.

Administration on Children and Families. (2019). Child abuse, neglect data released. Retrieved from https://www.acf.hhs.gov/media/press/2019/child-abuse-neglect-data-released

Adoption and Safe Families Act of 1997, 42 U.S.C.A. $\S 601$, et seq. \& $§ 671$ et seq.

Adoption Assistance and Child Welfare Act of 1980, 42 U.S.C.A. $\S 601$, et seq. \& $\S 671$ et seq.

Anh v. Levi, 586 F.2d 625 (CA 6 1978).

Baltimore City Department of Social Services v. Bouknight, 493 U.S. 549 (1990).

Bartholet, E. (1999). Nobody's children: Abuse, neglect, foster drift, and the adoption alternative. Boston: Beacon Press. 
Bartholet, E. (2015). Differential response: A dangerous experiment in child welfare. Florida State University Law Review, 42(3), 573-643.

Brecht v. Abrahamson, 507 U.S. 619 (1993).

Brodenkircher v. Hayes, 434 U.S. 357 (1978).

Child Abuse Prevention and Treatment Act, 42 U.S.C. $\S 5106$ et seq. (1974).

Children's Bureau. (2019, February). About CAPTA: A legislative history (Fact Sheet). Retrieved from https://www.childwelfare.gov/pubpdfs/about.pdf

Connecticut Department of Public Safety v. Doe, 538 U.S. 1 (2003).

Crawford v. Washington, 541 U.S. 36 (2004).

DeShaney v. Winnebago County Department of Social Services, 489 U.S. 189 (1989).

Duchesne v. Sugarman, 566 F.2d 817 (CA 2 1977).

Dwyer, J. G. (2016). Diagnosing liberal resistance to needed child welfare reforms. William \& Mary Bill of Rights Journal, 24(3), 595-602.

Family First Prevention Services Act 2018.

Fanshel, D., \& Shinn, E. B. (1978). Children in foster care: A longitudinal investigation. New York: Columbia University Press.

Fletcher, M. L. M., Singel, W. T., \& Fort, K. E. (Eds.). (2009). Facing the future: The Indian child welfare act at 30 . East Lansing: Michigan State University Press.

Gelles, R. J. (1996). The book of David: How preserving families can cost children's lives. New York: Basic Books.

Gelles, R. J. (2016). Why the American child welfare system is not child centered. William \& Mary Bill of Rights Journal, 24(3), 733-753.

Globe Newspaper Company v. Superior Court, 457 U.S. 596 (1982).

Gregory v. Ashcroft, 501 U.S. 452 (1991).

Griffin v. California, 380 U.S. 609 (1965).

Gundy v. United States, 138 S. Ct. 1260 (2018).

Hentoff, N. (1988, June 18). What protection for abused children? The Washington Post. Retrieved from https://www.washingtonpost.com/archive/opinions/1988/06/18/what-protection-for-abuse d-children/5ae77f4f-cf07-484c-902a-913b19eb4472/?noredirect $=$ on

Hughes, R. C., Rycus, J. S., Saunders-Adams, S. M., Hughes, L. K., \& Hughes, K. N. (2013). Issues in differential response. Research on Social Work Practice, 23(5), 493-520.

In re Baby X, 293 N.W.2d 736 (Mich. Ct. App 1980).

In re Burrus, 136 U.S. 586 (1890).

In re Gault, 387 U.S. 1(1967).

In re M.M., 133 A.3d 379 (Vt. 2015).

In re Troy D., 215 Cal. App. 3d889; 263 Cal. Rptr. 869 (1989).

In the Interest of L.J.B., 199 A.3d 868 (Pa. 2018). (2018).

Indian Child Welfare Act, 25 U.S.U. 1901 et seq. (1978).

Kennedy, R. (2003). Interracial intimacies: Sex, marriage, identity, and adoption. New York: Pantheon Books.

Kennedy v. Louisiana, 554 U.S. 407 (2008).

Lassiter v. Department of Social Services of Durham County, N.C., 452 U.S. 18 (1981).

Lehman v. Lycoming County Children's Services Agency, 458 U.S. 502 (1982).

M.L.B. v. S.L.J., 519 U. S. 102 (1996).

Maas, H. S., \& Engler, R. E. (1959). Children in need of parents. New York: Columbia University Press.

Maryland v. Craig, 497 U.S. 836 (1990).

McRoy, R. G. (2005). Overrepresentation of children and youth of color in foster care. In G. P. Mallon \& P. M. C. Hess (Eds.), Child welfare for the $21^{\text {st }}$ century: A handbook of practices, policies, and programs (pp. 623-634). New York: Columbia University Press.

Meyer v. Nebraska, 262 U.S. 390 (1923).

Miranda v. Arizona, 384 U.S. 436 (1966).

Multiethnic Placement Act (1994). 
Myers, J. E. B. (2006). Child protection in America: Past, present, and future. New York: Oxford University Press.

National Institute of Justice. (1998). The rights of crime victims - Does legal protection make a difference. Retrieved from https://www.ncjrs.gov/pdffiles/173839.pdf

New Jersey Division of Child Protection and Permanency v. Y.N., 104 A.3d 244 (2014).

Ohio v. Clark, 576 U.S. ; 135 S. Ct. 2173 (2015).

Pennsylvania v. Ritchie, 480 U.S. 39 (1987).

People v. Moreno, 744 N.E.2d 906 (Ill. Ct. App. 2001).

Pierce v. Society of the Sisters of the Holy Names of Jesus and Mary, 268 U.S. 510 (1925).

Prince v. Massachusetts, 321 U.S. 158 (1944).

Santosky v. Kramer, 455 U.S. 745 (1982).

Smith v. Doe, 538 U.S. 84 (2003).

Smith v. Organization of Foster Families for Equality \& Reform, 431 U.S. 816 (1977).

State v. Nutbrown-Covey, 204 Vt. 363 (Vt. Sup. Ct. 2017).

State v. Tate, 864 So. $2 d 44$ (Fla. Ct. App. 2003).

Stephenson, C. (2015, November 11). Boy at center of 'Poor Joshua!' Supreme Court case dies. Milwaukee Journal Sentinel. Retrieved from http://archive.jsonline.com/news/obituaries/ joshua12-b99614381z1-346259422.html/

Suter v. Artist M., 503 U.S. 347 (1992).

Terry, D. (1996, July 26). Mother sentenced to life in a killing that shook Chicago. The New York Times. Retrieved from https://www.nytimes.com/1996/07/26/us/mother-sentenced-to-life-in-akilling-that-shook-chicago.html

United States v. Holston, 343 F.3d 83 (CA 2 2003).

United States v. Lopez, 514 U.S. 549 (1995).

United States v. Nagarwala, 350 F.Supp. 3d 613 (E.D. Mich. 2018).

Vandervort, F. E. (2013). Protecting child witnesses on the witness stand: The law and the role of the forensic social worker in criminal proceedings. Journal of Forensic Social Work, 3(2), 150-175.

Vandervort, F. E. (2016). Federal legislation protecting children and providing for their well-being. In D. N. Duquette, A. M. Haralambie, \& V. S. Sankaran (Eds.), Child welfare law and practice: Representing children, parents, and state agencies in abuse, neglect, and dependency cases (pp. 231-274). Aurora: National Association of Counsel for Children.

Violent Crime Control and Law Enforcement Act of 1994.

Wilder v. Bernstein, 848 F.2d 1338 (2nd Cir. 1988).

Wisconsin v. Yoder, 406 U.S. 205 (1972). 